\title{
BOLESŁAW PRUS CZYTA BOURGETA. EMANCYPACJA, SPIRYTYZM I TEORIA POWIEŚCI
}

\author{
MARCIN JAUKSZ ${ }^{1}$ \\ (Uniwersytet im. Adama Mickiewicza w Poznaniu)
}

Słowa kluczowe: teoria kompozycji, spirytyzm, powieści Prusa i Bourgeta

Key words: theory of composition, spiritism, Prus's and Bourget's novels

\begin{abstract}
Abstrakt: Marcin Jauksz, BOLESŁAW PRUS CZYTA BOURGETA. EMANCYPACJA, SPIRYTYZM I TEORIA POWIEŚCI. „PORÓWNANIA” 13, 2013, t. XIII, s. 143-155. ISSN 1733-165X. Prusowska recenzja dzieła Uczeń Paula Bourgeta zamieszona w kronice „Kuriera Codziennego” jest przyczynkiem do refleksji o kształtowaniu się zrębów literackiej teoriipolskiego pisarza, który u kresu lat osiemdziesiątych zaczyna tworzyć swoje słynne notatki o kompozycji. W kontekście polemiki z Aleksandrem Świętochowskim, opublikowanych w tym czasie Emancypantek oraz dyskusji o spirytyzmie, jaka przetoczyła się na łamach warszawskiej prasy zimą 1893 roku, podjęta zostaje próba zaakcentowania tych fragmentów teoretycznych zapisków, które pokazują wciąż żywą nadzieję pisarza na kształtowanie postaw społecznych za pomocą literatury, literatury głoszącej inne prawdy niż te, które tak wiele krzywdy uczyniły bohaterom powieści Bourgeta.
\end{abstract}

Abstract: Marcin Jauksz, BOLESŁAW PRUS READS BOURGET. EMANCIPATION, SPIRITISM AND NOVEL THEORY. "PORÓWNANIA" 13, 2013, Vol. XIII, p. 143-155. ISSN 1733-165X. Published in "Kurier Codzienny" in 1889 Bolesław Prus's review of Paul Bourget's novel The Disciple is a starting point for this reflection on Polish writer's literary theory, who in the late 80s starts to collect his "reflections on composition". In the context of the famous polemic with Aleksander Świętochowski, Emancypantki - Prus's novel published in the early 90s and the press discussion in Warsaw of the winter of 1893, the author of the article attempts to highlight those of the reflections which show how deep was Prus's belief in a possibility to shape the reader's moral conduct through literature, literature which would promote truths different from the ones that make Bourget's characters' lives so miserable.

\footnotetext{
${ }^{1}$ Correspondence Address: ma_walden@wp.pl
} 


\section{CZĘŚĆ 1: \\ POŻYTEK Z „WCALE NIE PIERWSZORZĘDNEJ POWIEŚCI”}

„Powieść francuska rozlewa się po całej Europie, a każda zmiana zachodząca $\mathrm{w}$ tej dziedzinie francuskiej twórczości jest jakby zapowiedzią nowej epoki w cywilizacji"2 - te pamiętne słowa Bolesława Prusa à propos przedmowy Bourgeta do Ucznia ogłoszone w „Kurierze Codziennym” w ostatnim miesiącu roku 1889 pokazują, jak pisarz, którego druk pierwszej wielkiej powieści został już ukończony, nowa natomiast, jak pokazał Edward Pieścikowski, mimo podpisanej z „Kurierem" umowy, była jeszcze pieśnią przyszłości³, rozpoznawał zagadnienia, z którymi przyjdzie mu się mierzyć na łamach kolejnego dzieła z „wielkich pytań epoki". Uczeń Bourgeta był wydarzeniem, które, zdaniem Prusa, u kresu lat osiemdziesiątych zwiastuje nową epokę $\mathrm{w}$ prozie, choć nie tyle przez dzieło, co przez przedmowę doń, $\mathrm{w}$ której francuski autor stwierdzał:

Słuchaj mnie młody Francuzie. W tym wieku zaćmionych sumień i wzajemnie obalających się teorii chwytaj jak gałąź ratunku słowa Chrystusa: «Po owocach ich poznacie je». Jest prawda, jest rzeczywistość, o której nie możesz wątpić, bo ją posiadasz, czujesz, żyjesz nią w każdej chwili. Tą rzeczywistością jest - twoja własna dusza. Otóż między ideami, które wsiąkają w ciebie, są takie, które twoją duszę robią mniej zdolną do miłości i mniej zdolną do pragnień. Bądź pewnym, że te idee są fałszywe, choćby wydawały się najsubtelniejszymi, choćby wygłaszali je ludzie najsławniejszych nazwisk i najznakomitszego talentu4.

Przestrogi te, wykazać pragnie Prus, zwiastują nowy etap rozwoju literatury francuskiej definiowanej dotychczas przez pryzmat kategorii egotyzmu i rozpusty. Bourget ucieleśnia, według autora Lalki, typ autora, który dobrowolnie wzywa do przyjęcia więzów ideału, który posiada poczucie odpowiedzialności za głoszone słowa. I widzi w stanowisku zajętym przez Francuza znamię przemian, które dokonać się muszą, gdyż głos tego rodzaju może „przywrócić wszystko do porządku”.

Fakt, że z czasu powstawania Emancypantek nie ma żadnych teoretycznych zapisków dotyczących reguł kompozycji, co akcentował Edward Pieścikowski ${ }^{5}$, nie oznacza zdystansowania się względem określonych już reguł i nadziei wiązanych z konkretną poetyką twórczą. Wręcz przeciwnie. Można oczekiwać, że właśnie $\mathrm{w}$ tym dziele, mimo narzuconej przez okoliczności pracy nad powieścią $\mathrm{w}$ odcinkach, Głowacki konsekwentnie może wypróbowywać propozycje zawarte w „notatkach o kompozycji", wszystkie sposoby tworzenia fikcji literackiej i kreacji bohaterów na miarę czasów i potrzeb autora. Bo te - wydaje się - wyraźniej niż

\footnotetext{
2 B. Prus, Kroniki. Opr. Z. Szweykowski. Warszawa 1962, t. XII, s. 97.

${ }^{3}$ Zob.: E. Pieścikowski, „Emancypantki” Bolestawa Prusa. Warszawa 1970, s. 18.

${ }^{4}$ Cyt. za: B. Prus, op. cit., s. 98.

${ }^{5}$ E. Piescikowski, op. cit., s. 11
} 
w Lalce wysuwają się na plan pierwszy. Nie tylko dzięki wykładowi profesora Dębickiego.

Uznanie, jakie wyraża Prus dla przedmowy do Ucznia, zasługuje w tym kontekście na przypomnienie, określa bowiem ramy, w obrębie których umieszczał swą nową powieść pisarz, pozwala zastanawiać się, w jakim stopniu autor Emancypantek myślał o swoim powstającym dziele jako przynależnym do owej nowej epoki europejskiego piśmiennictwa. Ta epoka, można rekonstruować z wypowiedzi autora Kronik, renegocjować miała na kartach powstających dzieł społeczny powrót do ideału, odwrót od fascynacji światem zepsucia i użycia w kierunku „zaleceń Miłości i Woli”. Zdaniem Bourgeta, młodzi Francuzi winni - pod wpływem jego dzieła - odczuć „dreszcz wielkiej odpowiedzialności” ${ }^{6}$. Rok przed publikacją pierwszych odcinków Emancypantek Prus, pisząc o przedmowie do Ucznia, wyraża przekonanie, że wiara $\mathrm{w}$ ideały przemiany świata poprzez sztukę jest wciąż silnie zakorzeniona $\mathrm{w}$ wizji artysty mierzącego się ze światem, i - co może ważniejsze - że słowo odpowiedzialnie kształtujące rzeczywistość nie musi być tendencyjnie jednoznaczne. Ani na gruncie francuskim, ani w polskiej recepcji Uczeń nie okazał się dostatecznie jednoznaczny, co doprowadziło do wpisania przez środowiska konserwatywne powieści Bourgeta na listą lektur niebezpiecznych, również Emancypantki od tendencyjności są już zasadniczo odległe.

Jeszcze jeden element sprawia, że praca Bourgeta - w kontekście tego, co o niej mówi, ale też tego, czego o niej nie mówi autor Emancypantek - powinna być wzięta pod uwagę podczas lektury powieści o Madzi Brzeskiej. Psychologiczne kwestie mają dla Prusa w tej powieści dużo większe znaczenie - jak pokazywał bardzo szybko Ignacy Matuszewski, którego odczytanie tego dzieła w znaczny sposób wychodzi naprzeciw potrzebom i nadziejom Głowackiego. W szkicu Artysta i filozof akcentuje skupienie uwagi autora na "kwestiach czysto psychologicznych"7 i pokazuje, w jaki sposób ładunek refleksji przynosi odprężenie dla umysłu, który nie odnajduje w rzeczywistości argumentów pozwalających wierzyć $\mathrm{w}$ sukces idealistów. Ten stan rzeczy sprawia, że wywyższana we wspomnianym odcinku „Kronik” ponad Ucznia Zbrodnia i kara Dostojewskiego może i powinna funkcjonować w kontekście Emancypantek jako analityczna powieść wzbudzająca nadzieję na odrodzenie ludzkiego ducha, wydobycie go z mroków najczarniejszej otchłani. Z drugiej jednak strony - powodzenie ludzi złych i głupich w powieściach Prusa, na które zwraca uwagę Matuszewski, ma tu kapitalne znaczenie - Robert Grealson to fatalny punkt dojścia, którego rzetelny obserwator rzeczywistości wyrugować z niej nie może. Stąd w Emancypantkach idealistkom i idealistom dziać się musi źle, a wizja duchowego kryzysu nie zostaje zażegnana. Psychologiczne refleksje, z którymi Głowacki

${ }^{6}$ Zob.: B. Prus, op. cit., s. 99-100.

${ }^{7}$ I. Matuszewski, Artysta i filozof. W: O twórczości i twórcach. Studia i szkice literackie. Wybór i opr. S. Sandler. Warszawa 1965, s. 68. 
ma $\mathrm{w}$ tym czasie styczność, każą mu budować świat niejednoznaczny, rozpięty między między Bourgetem i Dostojewskim. Czy może - co stanie się przedmiotem refleksji - świat wpisany między przedmowę do Ucznia a samą powieść.

\section{CZĘŚĆ 2: MECHANIZMY NADZIEI, MECHANIZMY ZATRACENIA}

Świadomość, którą dzięki rozwojowi psychologii zyskują twórcy, łączy się $\mathrm{z}$ wpływem psychologicznych studiów na sposoby kreowania postaci w dziele. Dogłębnie przeanalizowanym już przypadkiem jest Płoszowski Sienkiewicza, którego w znacznej mierze tworzy polski pisarz z fascynacji Théodulem Ribotem zdaniem nie wszystkich jednak skutecznie:

I stało się, co było do przewidzenia: Sienkiewicz, mistrz wyższego rzędu, zdolny jednym machnięciem swego rycerskiego pióra trzem Bourget'om głowę uciąć - znajduje się na tej arenie niższym od Bourget'a; nie dorównywa mu w podglądaniu małostek i słabostek brzydkiej duszy, w odkrywaniu tajnych związków między psychologicznymi stanami, wywołanymi nie siłą logiki, ale newrozy. Nie jest dosyć obyty z tą sferą, ani dosyć oczytany z tą całą literaturą patalogiczno-fizjologiczno-psychologiczną. Mówi on wiele o nerwach, o popędach... ale czuć, że jest tu w obcej dziedzinie, że ze słyszanego kombinuje. Powiedziałbym, że Sienkiewicz ma duszę zbyt prostą i zdrową, zbyt szlachetną i sarmacką, aby się uganiać z tymi duszami skomplikowanymi, wyrosłymi na gruncie tej przejrzałej kultury, która czuje swój marazm, i sama się nazywa decadante i fin de siècle ${ }^{8}$.

Fragment powyższej recenzji jest symptomatyczny dla ówczesnej krytyki, wskazując potrzebę definiowania zależności między autorskim ",ja" a podmiotem opisywanym $\mathrm{w}$ dziele. Wciąż wyraźny prymat poświadczania fikcją własnego doświadczenia w literaturze pokazuje ciekawą i znamienną „drugą stronę" analizy zawartej w powieści Bourgeta - narzędzi, których nie sposób nie użyć na sobie, skoro ma się okazję, narzędzi, które muszą dowieść krachu wszelkich, również najbliższych sobie, wartości. Dla każdego z entuzjastów Sienkiewicza i zachowanego na kartach Trylogii "sarmackiego ducha” jego "naśladowanie z Bourgeta” musiało zabrzmieć fałszywie; podobnie jak sam Bourget, o którym sądy - przykładowo Cezarego Jellenty - nie akcentują moralnego zacięcia przedmowy, zaznaczając zarazem, w duchu komentarza redakcji „Prawdy” i stosunku samego Świętochowskiego do francuskiego dzieła, intelektualną bezradność demaskacji, jakich dopuszcza się naturalistyczna metoda czy Emila Zoli, czy Bourgeta.

8 M. Morawski, „Bez dogmatu” Henryka Sienkiewicza, „Przegląd Powszechny”, Tom XXVIII. (Październik, Listopad, Grudzień 1890). Kraków 1890. 
Stosunek Prusa do przeczytanej powieści jest na tym tle wyjątkowo ciekawy. Prus pisze, przypomnijmy,

Przeczuwaliśmy słuszną reakcję na wszystkich polach: $\mathrm{w}$ nauce, polityce, $\mathrm{w}$ urządzeniach rodzinnych i społecznych. I właśnie $\mathrm{w}$ tej samej porze, kiedy wydawało się, że wszystko jest przygotowane do dyktatury i inkwizycji, dyktator - upadł, a w dziedzinie na pozór oszalałej myśli francuskiej ukazały się znaki otrzeźwienia.

Samo dziennikarstwo poczyna występować przeciw szantażowi i nadużyciom reporterii.

Między powieściopisarzami znajdują się ludzie, którzy piętnują egoizm, karierowiczostwo i rozpustę, a zalecają Miłość i Wolę!...9

Odmowa wszelkiej wartości i głębi, tak przedmowie do Ucznia, jak i samemu dziełu przez redakcję „Prawdy"10, ma miejsce w czterdziestym ósmym numerze z roku 1889, na dwa tygodnie przed ukazaniem się „Kuriera” z opinią Prusa o przełomowości publikacji Bourgeta. Autor Lalki zatem, mimo że do poglądów redaktorów „Prawdy” się nie odwołuje, podejmuje szansę, jaką daje "niemoralne” dzieło Bourgeta, oceniając je przy tym dość surowo przez bezpieczne zestawienie z geniuszem Dostojewskiego, pozwala sobie wskazać na wartości wstępu, gdyż odnajduje istotny punkt odniesienia dla własnego pisarstwa. Elementy swojego programu ujmuje $\mathrm{w}$ planie szerokich zmian w literaturze europejskiej.

Na tle prowadzonej blisko dekadę wcześniej polemiki ze Świętochowskim o znaczeniu oświaty w podnoszeniu moralności społeczeństwa, akcent kładziony przez Prusa na wychowawczy charakter literatury, ukazuje sposób, w jaki wychowanie przez literaturę chce ostatecznie zdefiniować - jej użyteczność łączy się z samodzielnością czytelnika. To, jak chce ją widzieć, opisze właśnie w Stówku o krytyce pozytywnej w wielokrotnie cytowanej metaforze czytelnika-odkrywcy lasu - zły krytyk nie dostrzeże gałęzi, konarów czy drzew, gdyż wszystko przesłonią mu... liście.

Emancypantki pisane na fali pamiętnej polemiki wywołanej przez książkową edycję Lalki Prusa są poligonem okrzepłych w trakcie dyskusji tez spisanych wcześniej jako „notatki o kompozycji”. Powieść ta jednocześnie, można spodziewać się po ocenach nowych zjawisk literackich, w tym pisarstwa Bourgeta, miała stanowić próbę dyskusji ze współczesnymi prądami ideowymi, które niszczą młode pokolenie. Zgoda na program artystyczny wychowawczy wyrażony przez francuskiego pisarza $\mathrm{w}$ jego przedmowie ma ogromne znaczenie. Stanowić może bowiem argument $\mathrm{w}$ sprawie szans idealistów na funkcjonowanie $\mathrm{w}$ niewrażliwym i bezwzględnym świecie. Madzia Brzeska swoją historią powtarza wszystkie grzechy

\footnotetext{
9 B. Prus, op. cit., s. 100.

10 P. Bourget, Do Młodzieńca, Przedmowa Bourgeta do powieści „Uczeń". Przeł. L. Blumental, „Prawda" 1889, nr 48.
} 
naiwności Stanisława Wokulskiego, dorzucając do tego kilka własnych. Jednak prześledzenie choćby wątku miłosnego w Emancypantkach, szczególnie zaś w „nieocenzurowanej" wersji pierwodruku prasowego, w której finał całej opowieści tonął jeszcze $\mathrm{w}$ mrokach Prusowskiej fantazji, pozwala odczuć rangę inspiracji Bourgetowskich.

Historia młodego i wyrachowanego młodzieńca, którą dzięki manuskryptowi przekazanemu przez matkę oddanego pod sąd młodzieńca poznaje znamienity filozof Adrien Sixte, rzekomy inspirator duchowej deprawacji swego "ucznia”, to opowieść o bezwzględności, jaką generuje badawcze podejście do życia i dystans względem świata obserwowanego przez pryzmat psychologicznych i filozoficznych kategorii. Psychologiczny eksperyment, który na samym sobie i panience $\mathrm{z}$ dobrego domu, w którym jest preceptorem, przeprowadza tytułowy bohater powieści Bourgeta, pozwala ukazać ogrom wymiaru deprawacji, jaka może wyniknąć ze zbytniego przejęcia się scjentystycznym optymizmem - tak ważnym przecież dla epoki - prowadząc do reifikacji ludzkich relacji i zupełnego odpodmiotowienia badań nad człowiekiem. Jednocześnie - wyznanie Roberta dotyczące sposobu oddziaływania nań prac mistrza - nie mogło nie przejąć Prusa-wychowawcy:

Potężna logika twego rozumowania znalazła odzew w mym umyśle. Poddawszy się z pokorą pańskiemu przewodnictwu, wytworzyłem sobie wreszcie całokształt trzeźwych i racjonalnych poglądów: ujrzałem wszechświat takim, jakim jest $w$ istocie, zrozumiałem, że niezmierzona fala zjawisk nie ma początku i nigdy końca mieć nie będzie. (...) Ach! Jakimiż słowami wyrażę trawiącą mnie wtedy gorączkę śledzienia prawdy, gorączkę podobną poniekąd do szału pierwszej miłości! Doznawałem uczucia radości fizycznej, burząc wspaniały gmach wyobrażeń, którymi żyłem dotąd. Każde słowo pańskie wydawało mi się hymnem $(. . .)^{11}$.

Religijno-miłosne uniesienie, które charakteryzuje lekturę tytułowego bohatera, zwraca uwagę w kontekście wykładanego dekadę później przez Prusa estetyczno-filozoficznego credo w Najogólniejszych ideałach życiowych: „Literatura piękna posługuje się wyrazami jak najbardziej potrącającymi o zmysły i uczucia, zaś "cechy ogólne" ukazuje w związkach życiowych"12. Geslou zatem czyta traktaty filozoficzne Sixte'a, jakby czytał literaturę piękną; emocjonalny styl odbioru doprowadzi go do psychologicznej zbrodni, jednocześnie jednak stanowi fantazję na temat oddziaływania idei odpowiednio przedstawionej w dziele.

Bowiem powieść Bourgeta to nie tylko fabuła ku przestrodze, ale też katalog możliwych sposobów uwodzenia słowem. Wykorzystanie przez Greslou zadomowienia bohaterki $w$ konwencjach romantycznych, zmyślnie skonstruowana na

\footnotetext{
11 P. Bourget, Uczeń. „Przegląd Tygodniowy” 1889, nr 26, s. 344.

12 B. Prus, Najogólniejsze ideały życiowe. Warszawa 1900, s. 118.
} 
jej użytek historia własnego życia pełna niedopowiedzeń i tajemnic, sprytny wybór Eugenii Grandet Balzaka do głośnego czytania podczas wspólnych wieczorów w salonie - wszystko to szczeble na drodze do oczywistego sukcesu bohateraintryganta, ale też katalog literackich manipulacji, które zniewalają odbiorcę i usidlają jego/jej emocje, prowadząc w dowolnie obranym kierunku. Choć Bourget nie zdradza zbyt wiele z uczuć Karoliny, to jednak pośrednio wiadomym jest, jak silny efekt wywiera na niej nowy wychowawca brata. Madzi zauroczenie Kazimierzem jest podobnego rodzaju, choć wybory obu bohaterek różnią się znacząco od siebie; sama pokusa jednak, jak pokazywał Pieścikowski, zwłaszcza w pierwotnym zamyśle miała kłaść się fundamentem pod gmachem psychologicznego portretu Brzeskiej. Kazimierzowi z kolei daleko do bohatera Bourgeta jeśli chodzi o oczytanie, choć $w$ przypadku obydwóch to, co im się udaje jest w równej mierze efektem ich atrakcyjności, co wyrafinowanej gry z uwodzoną kobietą. Robert Greslou zresztą, mimo pretensji do psychologicznej przenikliwości, ostatecznie sam rozpoznaje swoje "błędy" i fałszywe posunięcia... Ten chłodny analityk toczy zażartą bitwę ze swoim pracodawcą, markizem de Jussat, na pole starcia oznaczając duszę "wybranki swego rozumu” i ostatecznie czyni z niej bardzo ważną heroinę w tym dramacie emocji i wyrachowania.

Rozstrój nerwowy Madzi w Emancypantkach to kolejny przykład choroby wieku, który odciska swe piętno na wrażliwych umysłach. Prus, zmieniając optykę i spoglądając na bohaterkę raczej, niż na uwodziciela, pokłada nadzieję w czytelniczej empatii, która pozwoli na wyrozumiałość dla naiwności i potępienie dla wyrachowania. Ucieczka Madzi przed światem to konieczność, choć nie ostateczność. Tego horyzontu ocalenia polski pisarz swoim czytelnikom odbierać nie zamierza. $\mathrm{Z}$ drugiej strony, Karolina u Bourgeta, osaczona uczuciem, któremu ulec nie powinna, szuka ucieczki i to ucieczki desperackiej. Jej powrót do domu, do chorego brata ma wymiar heroiczny. Bohaterka Prusa, którą czytelnik widzi w ostatnim rozdziale powieści, to osoba - można powiedzieć - zupełnie oderwana od rzeczywistości. Los, który w ten sposób zawiesza Prus, nie dopełnia się zatem tak samo kategorycznie, jak droga życiowa Karoliny, ale wyraziściej może tym samym akcentuje autor Emancypantek kondycję podmiotu kierowanego wewnętrznym przymusem dobroci, kierowanego wciąż - fatalnie - ku porażce.

Na szczególną uwagę zasługuje mechanizm wpływu, jakiemu ulegają bohaterowie Bourgeta i Prusa. Przemoc idei, na którą zwracał uwagę w swej przedmowie francuski pisarz, degeneruje Roberta, młodzieńca inteligentnego, nieustannie, zdaje się, ostrzącego skalpel autoanalizy, wytrąca też z równowagi Madzię Brzeską $\mathrm{w}$ finalnym rozdziale tomu trzeciego Emancypantek. Prus pokazuje na swej bohaterce jeden z tych momentów, w którym „wewnętrzna istota człowieka doznaje niekiedy wzruszeń podobnych do trzęsienia ziemi"13. Podczas wieczoru u Solskich

${ }^{13}$ B. Prus, Emancypantki. Red. Z. Szweykowski. Warszawa 1949, t. III, s. 221. 
Prus jednoznacznie określa rolę Kazimierza, który mówi o złudzeniu, że natura została stworzona przez siłę podobną do człowieka, który może mieć cele, który może być litościwy... Przyrównując ludzi do chmur na niebie wyraża niezbyt poruszające jego samego przekonanie, że ludzkie istnienie nie ma celu, że metafizyczne pragnienia pozbawione są podstaw. Porównanie to dotyka jednak zapatrzoną weń bohaterkę, która

rozgorączkowana, przestraszona, szarpała chusteczkę. Pan Kazimierz był dla niej genialnym człowiekiem i wątpić o prawdzie jego słów nie potrafiłaby; przynajmniej teraz, kiedy patrzy w jego cudowne oczy, głęboko rozumne a tak smutne.

On, widać, już pogodził się ze strasznym losem człowieka, więc dlaczegóżby ona miała oburzać się przeciw nieugiętemu prawu $?^{14}$

Prosto i skutecznie przypomina tu Prus na jakich zasadach Kazimierz Norski jest dla Madzi autorytetem. Pensjonarskie zakochanie młodej dziewczyny ma poważne skutki jeśli chodzi o dystrybucję niebezpiecznych przekonań. Załamanie, które będzie konsekwencją tej błahej z perspektywy mężczyzny rozmowy, pozwala Prusowi ukazać, jak prosto budują się więzi, które umożliwiają cyrkulację właściwie każdej idei... Czytelnik oczywiście zdanie o talentach i głębi prawd głoszonych przez młodego utracjusza miał okazję wyrobić sobie już wcześniej; teraz zaś stanie przed zadaniem objęcia głębi kryzysu wywołanego przez fałszywy seans spirytystyczny.

Prawdy objawione przez Kazimierza, można się domyślać, nie bez powodu spotykają się $\mathrm{w}$ czasie $\mathrm{z}$ chwilą spirytystycznego rozczarowania Madzi. Zdemaskowawszy fałszywość inscenizacji, automatycznie uznaje możliwą korzyść, jaką $\mathrm{z}$ wiary w jej autentyczność będzie miało rodzeństwo Solskich. I jest to moment kluczowy, moment w którym pod wieloma względami podporządkowana mądrości mężczyzn Madzia wyłamuje się z bezradności i analizuje sytuację dojrzale, $\mathrm{z}$ dystansem właściwym samemu pisarzowi. Potrzeba sensu, która wisi w powietrzu nad wszystkimi darzonymi sympatią bohaterami, czyni z Madzi mistrza ceremonii, osobę, która doznawszy rozczarowania, nie chce odbierać złudzeń innym. Sama popada w „zupełny sceptycyzm”, zapraszając czytelnika do podążenia za nią ku doświadczeniom tomu czwartego.

\section{CZĘŚĆ III: MISTRZ}

W innej, dla wielu najważniejszej, opowieści Prusa, paryskie spotkanie z magnetyzerem Palmierim jest dla Wokulskiego czymś na kształt straconej szansy. Odkrywszy, że seanse mediumiczne nie są kuglarstwem, dowiaduje się o własnej

14 Ibidem, s. 220. 
odporności na wszelką działalność hipnotyczną. To z powrotem wtrąca go w trud samodzielnego rozpoznania, co jest prawdą, co złudą, co realną nadzieją, co zaledwie iluzją tejże. Myśli krążące na przemian to wokół panny Izabeli, to wokół odwiedzin Geista nie są tu jednak najważniejsze. Istotne jest natomiast zainteresowanie hipnotyzmem Głowackiego, któremu daje on wyraz nie tylko na kartach swych powieści, ale też $\mathrm{w}$ Kronikach, $\mathrm{w}$ pamiętnych fragmentach, gdy bierze w obronę Ochorowicza i jego zainteresowania. Ten popularyzator mediumizmu w Polsce dał im wyraz podczas warszawskich odczytów w roku 1888. Odczuwający sceptycyzm względem mediumizmu Głowacki wyraża jednak - nawet w swych krytycznych i ironicznych aranżacjach tematu - szczególną fascynację hipnotyzmem. Duchy, których możliwość istnienia dopuszcza, nie interesują go jednak same w sobie. Zainteresowany Prus jest de facto fascynacją sublimacyjnym charakterem spirytyzmu, który zastępuje inne wiary, stanowiąc ersatz dawnych wzruszeń metafizycznych czy poetyckich:

Oto co mówi spirytyzm do milionowych rzesz spragnionych ideału:

Wygnaliście Ducha z Natury, macie duchy w mieszkaniach i sprzętach.

Odrzuciliście natchnienia poezji, macie „transe" mediów.

Pogardziliście filozofią metafizyczną, słuchajcie teraz nóg stołowych.

Z tych powodów spirytyzm i mediumizm wydaje mi się faktem poważnym, którego niepodobna zbywać ironicznym uśmiechem ani machnięciem reki ${ }^{15}$.

Te uwagi, ogłoszone w „Kurierze Codziennym” w 1893 roku, wpisują się w czas refleksji o duchowym przełomie początku lat dziewięćdziesiątych i stanowią interesujące, pozytywistyczne pendant do dyskusji o charakterze młodopolskiej „metafizyki”. „Nowa wiara” w oczach Prusa to przede wszystkim nowy fakt społeczny i jej użyteczność w tym względzie wymaga namysłu. Instynktownej obrony złudzeń dopuszcza się też porażona sceptycyzmem Norskiego Brzeska, której decyzja w tym powieściowym momencie jest dalekim pogłosem przemyśleń samego Prusa. Postawa pisarza spotkała się - jak wiadomo - z niezrozumieniem krytyków i demaskatorów Eustapii Palladino, którzy nie rozumieli wyrozumiałości Głowackiego, decydującego się cierpliwie czekać na rozwój mediumicznych przypadków. Pisarz wszelako przedkładał wartość drzemiącego w nowej modzie natchnienia i inspiracji, nad ewentualne szkody wynikłe z udziału w oszustwie. Fakt, że podobnie wcześniej pozwolił rzecz rozstrzygnąć bohaterce Emancypantek, w jakiś sposób wspiera argument o braku ekstremizmu w sądach wydawanych na przełomie 1893 i 1894 roku. Dalszy rozwój badań nad duszą i zasadami rządzącymi wszechświatem natomiast obiecywał przekucie spirytystycznego kapitału w coś bardziej wartościowego:

15 B. Prus, Eustapia Palladino, „Kurier Codzienny” 1893, nr 353. Cyt. za: B. Prus, Listy. Opr. K. Tokarzówna. Warszawa 1959, s. 200. 
Dopiero gdy najnowsza fizyka na dnie swoich eterów i falowań odnajdzie ducha w naturze, a psychologia zwiąże go z uczuciem i pragnieniem człowieka, dopiero wówczas stoły umilkną, a media przestaną być przedmiotem godnych podziwu obserwacyj ${ }^{16}$.

Zachwyt nad dydaktycznym zwrotem we francuskiej literaturze łączy się u Prusa z poszukiwanym na gruncie tak teorii, jak i literackiej praktyki, sposobem połączenia tych pozostających $\mathrm{w}$ rozbracie pierwiastków. Pojęcia uczucia i pragnienia mają tu zwłaszcza ważkie pragnienie, gdyż (możliwe do wywiedzenia choćby z estetyki Jana Marii Guyau) to one kładą się fundamentem pod polemiczne względem teorii Kanta czy Spencera ujęcie piękna:

To, co jest piękne, jest w tym samym stosunku pożądane. Poezja rzeczy, mówiąc słowami Alfreda de Musset, cała utkana jest z „bojaźni i uroku”, pomieszania i pragnienia. Nie ma wzruszenia estetycznego, które by nie budziło w nas wielu pragnień i więcej lub mniej nieświadomych potrzeb $(\ldots)^{17}$.

U Guyau, którego oryginalne wydanie z roku 1884 posiadał Prus w swym księgozbiorze, emocje, którymi rządzi sztuka, łączą się z praktycznym i ideowym kontekstem zjawisk i rzeczy. Inspiracyjny charakter tego, co estetyczne, nie daje się odsunąć na dalszy plan. I w tym kontekście przyklaśnięcie przez autora Lalki przedmowie do Ucznia można uznać za jeszcze jeden głos w sprawie wychowania powszechnego, w sprawie literatury tworzonej odpowiedzialnie i z myślą o konkretnych efektach. Relacja między bohaterami Bourgeta pokazuje złe skutki wychowania; Prus pragnie - jak dowodzą "notatki o kompozycji” - wychowywać świadomie i w słusznym celu.

Tym samym przejściowy charakter fascynacji spirytyzmem mógł mieć dodatkowe - mniej społeczne, a bardziej praktyczne - znaczenie, przekładające się na poetykę pisarza. Hipnotyzm, promowany przez Ochorowicza jako sposób leczniczy, zaciekawił Prusa na czas na tyle długi, by można dziś ukuć hipotezę, że zainteresowanie to łączyło się z nadzieją praktycznego wykorzystania technik kontroli wypracowanych przez hipnotyzerów na polu literatury. Każdy, kto pochylał się nad Prusowskimi zapiskami, wie, że wątek konkretnego komunikatu wywołującego zamierzony efekt $\mathrm{w}$ duszy odbiorcy to leitmotiv tych rozważań ${ }^{18}$. Teoria ma upewnić autora w słuszności podjętych kroków i działań.

Trzeba pisać tak, aby pojęcia oderwane symbolizować realnymi, które w duszy czytelnika wywołają efekt zamierzony.

16 Ibidem.

17 J. M. Guyau, Zagadnienia estetyki wspótczesnej. Przeł. S. Popowski. Warszawa 1901, s. 37-38.

18 Pisałem o tym w artykule Między niebem a ziemia. Relacje miedzy człowiekiem a jego przestrzenia jako element psychologicznych rozgrywek Bolesława Prusa z jego wspótczesnościa, „Porównania” 2012, nr 11, s. 122-123. 
Dalej - panować nad wyborem przedmiotów w ten sposób, ażeby wybrany symbol budził wyraźną ideę, ale jeszcze określone uczucie ${ }^{19}$.

Potrzeba kontroli, która nie raz wybrzmiewa w tych zapiskach, poświadcza umiłowanie konkretu, ale jednocześnie wyraża nadzieję manipulacji „w słusznej sprawie". Wychowawca w Głowackim żył, jak wiadomo, od najmłodszych lat jego piśmienniczej działalności. W teoretycznej nadziei Prusa wiązanej z pisarskimi możliwościami przejawia się ambicja dużo dogłębniejsza, dalece bardziej też wyrafinowana. Wpływanie na wolę czytelnika niedalekim jest $\mathrm{w}$ istocie od inspirującego działania hipnotyzera, hipnotyzera, który, jak stwierdzał w Chorobach woli znany Głowackiemu Ribot, może nakazać wykonanie pewnej czynności nawet z opóźnieniem przy ich pełnym przekonaniu o niezawisłości przedsięwziętych postanowień. Zgodnie z definicją Spinozy, również cytowaną przez Ribota, „nasze złudzenie woli (...) jest tylko nieznajomością pobudek, zmuszających nas do działania" 20.

Tu odkryte być może ponownie znaczenie, jakie dla Prusa ma przedmowa do Ucznia. Adresowana do „współczesnego młodego człowieka”, akcentuje kwestię odpowiedzialności za słowo i nauki, które się głosi, a także wyraża nadzieję na odkrycie drogi pomiędzy zwodniczą alternatywą, jaką stwarza francuska duchowość końca wieku, a możliwościami, jakie daje wychowanie poprzez odpowiednią prezentację rzeczywistości w dziele literackim. Prus nie tworzy podobnej przedmowy, jego interakcja ze współczesnością - jako publicysty i jako dziennikarza o podobne jednak fundamenty się opiera. Program polskiego pisarza nie jest przez to oczywisty w tym samym stopniu, odnajdywane są jednak przesłanki, które pozwalają pisać o ukierunkowaniu prac nad techniką pisarską nie tyle wychodzącą na poszukiwanie czytelnika idealnego, co stwarzającą go dzięki odpowiednim technikom, roboczo powiedzmy, sugestii.

Jan Władysław Dawid, z którym Prus zresztą często polemizował (panowie nawzajem nieraz podawali w wątpliwość swoje kompetencje psychologiczne), w szkicu O poddawaniu uczuć zdaje się przychodzić w sukurs potrzebom autora Emancypantek w jego próbach ustalenia, którędy wiedzie droga do sukcesu sugerowania i prowokowania konkretnych emocji.

Wśród objawów snu hipnotycznego stwierdziliśmy fakt pojawiania się uczucia w następstwie nadanej postawy i wyrazu. Analizując zjawisko, znaleźliśmy, iż głównym jego momentem jest zasada najsilniejszego skojarzenia dwóch stanów: uczucia i ruchu ekspresyjnego; że współczynnikami, które ów moment określały były: hipnotyczne znieczulenie, bezmyślność i bezwola, i jako wynik otrzymaliśmy, iż przy tych warunkach zjawisko było koniecznym. Przeniósłszy się następnie na grunt normalnie psychologiczny, znaleźliśmy tutaj czynną tę samą zasadę skojarzenia, lecz w odmiennem oto-

\footnotetext{
19 B. Prus, Literackie notatki o kompozycji. Wybór i opr. A. Martuszewska. Gdańsk 2008, s. 53.

20 T. Ribot, Choroby woli. Przeł. 1 J. K. Potocki, Warszawa 1885, s. 137.
} 
czeniu: normalnej wrażliwości, wyobraźni i uwagi; a wobec tych warunków bardziej złożonych, wywnioskowaliśmy, iż zjawisko, choć nie jest koniecznym, jest możliwem, $\mathrm{i}$ to w stopniu mniejszym lub większym, zależnie od zachowania się przyjaznego, obojętnego lub wrogiego czynników takich jak wrażenia, wyobrażenia, uczucia i wola, z uwzględnieniem stanu powtórzeńn ${ }^{21}$.

Prawo o możliwości sugerowania zachowań i emocjonalnego zjednywania sobie ludzi ma charakter niezwykle ważki na tle - po pierwsze - hipnotycznych zainteresowań Prusa, po drugie zaś - w kontekście epoki, która wydatnie wykorzystuje pojęcia sugestii, sugerowania wrażeń. Faktem bezdyskusyjnym jest, że Prus w swych technikach manipulacji artystycznej wyrasta ze szkoły tendencyjnej, nie zaś symbolistycznej, niemniej jednak jego praca w obrębie notatek o kompozycji wyraźnie wskazuje na żywotność potrzeby przeprowadzenia czegoś na kształt opisywanej przez Dawida interakcji w przestrzeni literackiej. Hipnoza, którą jako szczególny przypadek wpływu na wolę wykorzystuje Dawid, jest tropem niezwykle atrakcyjnym. W myśl bowiem klasyfikacji dokonanej w Emancypantkach:

są geniusze woli, którzy mają wielkie cele i umieją robić odpowiednie plany, choć nie zawsze dopisują im środki. Są geniusze myśli, których wzrok ogarnia bardzo szeroki horyzont i trafia w rdzeń każdej kwestii, lecz znowuż ci nie zawsze znajdują słuchaczów. I są geniusze uczucia, którzy (...) czują za wszystko i wszystkich, lecz sami u nikogo nie znajdują oddźwięku.

Cytowany już Matuszewski odwołuje się do tego fragmentu, szukając miejsca Madzi w porządku rzeczy. Ważne jednak niemniej jest, gdzie na tej genialnej mapie odnajduje się sam Prus, myśliciel, który decyduje się naruszyć granice niepoznawalnego - tak kategorycznie wykreśloną przez Spencera i zagrać w psychologiczną grę poddawania uczuć. Wymaga to odnalezienia odpowiednich środków, sprawia też, że myśl wreszcie trafi i wywoła wrażenie, konkretne wrażenie, to, które było zaplanowane.

Prus-artysta i Prus-filozof Matuszewskiego to ktoś jeszcze, to człowiek, którego Emancypantki opowiadają o samym autorze równie dokładnie jak o centralnych postaciach tej narracji i związki miedzy nimi pokazują mechanizmy psychiki samego powieściopisarza. Ekspresywny charakter tej prozy, zdaniem Matuszewskiego, powala odnaleźć ów "złoty klucz, otwierający nam tajniki jego umysłu i serca i tłumaczący budowę jego własnego świata". Koncepcja podmiotu autorskiego skorelowana $\mathrm{z}$ wizją świata przedstawionego dookreśla - roboczo, w jednej z pierwszych recenzji Emancypantek - cezurę w sposobie czytania Prusa.

Człowiek nie jest przecież automatem, zawieszonym luźno i podrygującym swobodnie w przestrzeni; nie, to raczej marionetka, od której członków idzie na dół i w górę, na

${ }^{21}$ J. W. Dawid, O poddawaniu uczuć. W: Szkice psychologiczne. Warszawa 1890, s. 85. 
prawo i na lewo tysiące drutów, drucików, nitek i sznurków, łączących ją ze światem oraz innymi marionetkami i wpływających w mniej lub więcej widoczny sposób na swobodę i kierunki jej ruchów. Otóż Prus, spojrzawszy na człowieka, dostrzega od razu wszystkie te nitki; lecz zamiast, jak to - dla ułatwienia sobie roboty - czynią inni, przeciąć je i pozrywać, pozostawiając tylko parę niezbędnych, najgrubszych sznurów, stara się uwzględnić i odtworzyć całą tę skomplikowaną siatkę motywów życiowych.

Dlatego tez Prus, który jest doskonałym psychologiem, nie napisał nigdy tak zwanej powieści psychologicznej w stylu Bourgeta i Roda i innych wyrafinowanych impotensów współczesnej literatury francuskiej. On zawsze widzi i maluje nie tylko jakiś wyjątkowy stan, namiętność, uczucie, ale całego człowieka, razem z jego rodziną, przyjaciółmi, wrogami, służbą, zajęciami, sprzętami, domem etc. ${ }^{22}$

Dysonanse, które rozdzierają ten świat, stają się dla Matuszewskiego tym samym zwierciadłem rozdarć samego autora, zwierciadłem jednak z całą pewnością pozbawionym pęknięć i rys. Czytelnik umarionetkowiony? Nie... Raczej nie. Ale Prus otwierający dla Matuszewskiego nowy rozdział w romansopisarstwie mógłby uśmiechnąć się nad taką reakcją z zadowoleniem, nawet jeśli zmierzającą ku trudnej identyfikacji, która w kontekście Ucznia Bourgeta - w finale powieści i w finale tego tekstu - nasuwa się sama.

Gdy po egzekucji Gralsona u stóp jego łóżka Adrien Sixte poszukuje słów modlitwy, poczucie krachu ideału możliwej teorii uczuć i psychologii doskonałej zdaje się ostateczne. Można by powiedzieć, że swój negatywny finał spotykają tu pozytywistyczne nadzieje samego Głowackiego. Można, ale nie należy. Nie jest bowiem to krach zupełny, skoro pisarz akcentował będzie większa wagę przedmowy Bourgeta niż powieści samej. W świetle tej dramatycznej sceny zupełnie innego znaczenia nabierają słowa Prusa, że powieść ta kończy się tam, gdzie prawdziwie wielka powieść - Zbrodnia i kara - się zaczyna. Jeśliby zatem Prusowi w jego krytyce chodziło nie o ucznia, ale o mistrza, Emancypantki byłyby próbą korekty programu, którego wychowawczy potencjał w przerażający sposób został pokazany. Emancypantki - już na własny rachunek - opowiadają o przekroczeniu granic chorobliwego rozchwiania. Wciąż twórczy ma być znak zapytania zawieszony nad światem, wciąż ważka jest propozycja budzenia Carlyle'owskich herosów, geniuszy woli, myśli i uczucia a hipnotyczny projekt Prusa wciąż czeka na dopełnienie i na swoich - oby lepszych od Greslou - uczniów tamtych czasów.

22 I. Matuszewski, Artysta i filozof („Emancypantki"), w: O twórczości i twórcach. Studia i szkice literackie. Wybór opr. S. Sandler. Warszawa 1965, s. 52. 
